Nutr. Metabol. 1974;16:I-IV

\title{
Contents, Vol. 16, 1974
}

Nutrition and Metabolism

Journal of Nutrition, Metabolic Diseases and Dietetics

N. Zöllner, München

E.M.Widdowson, Cambridge G. Wolfram, München

Main Editor Associate Editor

Editorial Board

W. Auerswald, Wien

E. Le Breton, Paris

H.-D. Cremer, Giessen

F.Falkner, Yellow Springs,

Ohio

F. Fidanza, Perugia

R. GITZELMANN, ZÜחCh

G. Hartmann, Bern

G. Den Hartog, Den Haag

K. Hellström, Stockholm

B. Hess, Dortmund

B. Jacotot, Créteil

H. Kapp, Basel

I. Macdonald, London

H. K. Mangold, Münster

R. Nicolaysen, Oslo

T. R. E. Pilkington, London

E. Rossi, Bern

H. Sarles, Marseille G. Schlierf, Heidelberg J. C. Somogyi, Zurich J. Trémolières, Paris A. J.

Vergroesen, Vlaardingen/Nederland J. F. De Wijn, Zeist A. Wretlind, Stockholm

S. Karger $\cdot$ Basel $\cdot$ München $\cdot$ Paris $\cdot$ London $\cdot$ New York $\cdot$ Sydney

Index

No. 1

Chan, J.C.M. (Washington, D.C.): The Influence of Dietary Intake of Endogenous

Acid Production. Theoretical and Experimental Background

Shenolikar, I. S. (Hyderabad): Protein Nutrition and Calcium Absorption 10

Lemonnier, D.; Gasquet, P. de; Griglio, S.; Naon, R.; Reynouard, F., and

Trémolières, J. (Paris): Effect of Dietary Vitamin B Level on Fat Storage,

Adipose Tissue Cellularity and Energy Expenditure in Rats and Mice Fed a

High-Fat Diet 15

Kaufmann, N.A.; Poznanski, R., and Guggenheim, K. (Jerusalem): Teen-Agers

Dieting for Weight Control 30 
Alling, Ch.; Bruce, Å.; Karlson, I., and Svennerholm, L.(Göteborg): The

Effect of Different Dietary Levels of Essential Fatty Acids on Growth of the Rat 38 Guo, L. S. S. and Alexander, J. C. (Guelph): Comparative Studies on Composition of Liver Phospholipids from Rats Fed Oleic or Elaidic Acid

51

Necrology - Nekrolog - Nécrologie 64

No. 2

Fox, I. H. (Toronto): Purine Ribonucleotide Catabolism: Clinical and Biochemical Significance. Review 65

Raptis, S.; Dollinger, H.; Rothenbuchner, G.; Fussgänger, R.; Klör, U., and Pfeiffer, E. F. (Ulm): Effect of Acetazolamide on the Insulin Response tolntravenous Administration of Secretin 79

Cutler, M.G. and Hayward, M.A. (Birmingham): Effect of Lipid Peroxides on

Fat Absorption and Folic Acid Status in the Rat 87

Björn-Rasmussen, E. and Hallberg, L. (Göteborg): Iron Absorption from Maize. Effect of Ascorbic Acid on Iron Absorption from Maize Supplemented with Ferrous Sulphate 94

Björn-Rasmussen, E. (Göteborg): Iron Absorption from Wheat Bread. Influence of Various Amounts of Bran 101

Seetharam Bhat, K. (Hyderabad): Riboflavin Deficiency and Galactose Meta bolism in Human Subjects 111

Johnson, P.C.; Rambaut, P.C. and Leach, C. S. (Houston, Tex.): Apollo 16 Bio

Energetic Considerations 119

Book Reviews - Buchbesprechungen - Livres nouveaux 127

No. 3

Jourdan, M.H. (London): Endogenous Glyceride Synthesis Rate in Baboons Fed Diets Containing Sucrose or Glucose

Index III

Chan, J. C. M. (Los Angeles, Calif.): Effect of Milk Formulae on Acid Balance .... 140

Jeffers, D.B. and White, I.R. (London): Influence of a Combined Oral Contra ceptive upon Rats Fed Low Protein/High Carbohydrate Diets 155

Kuhn, E.; Stríbrná, J.; Schück, O.; Brodan, V., and Válek, J. (Prague): Renal

Response to a Water Load in Normal Fasting Subjects 163

Prasad, C. U. and Bose, S. M. (Madras): Effect of Protein Deficiency on Cross-

Linking and Maturation of Collagen 172

Alling, C; Bruce, Å.; Karlsson, L., and Svennerholm, L. (Göteborg): The

Effect of Different Dietary Levels of Essential Fatty Acids on Body Composition

of the Rat 181

Varia 192

No. 4

Válek, J.; Grafnetter, D.; Fabian, J., and Belán, A. (Prague): Analysis of Lipid

Disturbances in Patients with Angiographically Confirmed Coronary Artery

Disease 193

Mokady, Sh. (Haifa): Effect of Dietary Pectin and Algin on the Biosynthesis of

Hepatic Lipids in Growing Rats 203

Visser, W.J.; Bellot, S.M.; Duursma, S.A., and Luyken, R. (Utrecht): Osteo

porosis in Surinam 208 
Dvorak, M. (Brno): Effects of Corticotrophin, Starvation and Glucose on Ascorbic Acid Levels in the Blood Plasma and Liver of Piglets 215

Holmgren, G. (Umeå): Effect of Low, Normal and High Dietary Protein Intake on Urinary Amino Acid Excretion and Plasma Aminogram in Children 223

Naismith, D. J. and Rana, I. A. (London): Sucrose and Hyperlipidaemia. I. The Relationship between the Plasma Lipid Concentration and Enzymes of Tissue Lipogenesis 238

Alling, Ch.; Bruce, Å.; Karlsson, I., and Svennerholm, L. (Göteborg): Effect of Different Dietary Levels of Essential Fatty Acids on the Fatty Acid Compo sition of Lecithin in Rat Skeletal Muscle 249

Book Reviews - Buchbesprechungen - Livres nouveaux 260

No. 5

Drouin, P.; Mejean, L.; Guisard, D. et Derby, G. (Nancy): Application de la méthode des enregistrements continus de glycémie à Гétude de Faction des substances hypoglycémiantes chez le diabétique 261

Mejean, L.; Drouin, P.; Guisard, D. et Derby, G. (Nancy): Méthodes d'interprétation de Tenregistrement continu de la Glycémie 268

Semprini, M.E.; D'Amicis, A., and Mariani, A. (Rome): Effect of Monosodium Glutamate on Fetus and Newborn Mouse 276

IV

Index

Naismith, D.J. and Rana, I. A. (London): Sucrose and Hyperlipidaemia. II. The Relationship between the Rates of Digestion and Absorption of Different

Carbohydrates and their Effects on Enzymes of Tissue Lipogenesis 285

Naismith, D.J.; Stock, A.L., and Yudkin, J. (London): Effect of Changes in the Proportions of the Dietary Carbohydrates and in Energy Intake on the Plasma Lipid Concentrations in Healthy young Men 295

Rocquelin, G.; Astorg, P. O.; Peleran, J. C. et Juaneda, P. (Dijon): Influence des huiles de colza et de canbra sur les lipides plasmatiques du rat 305 Hoekstra, D.; Berger, R., and Hommes, F.A. (Groningen): Thiamine Diphosphate Content of Liver Mitchondria of the Pregnant and Developing Rat 317 Varia 324

No. 6

Decken, A. von der and Omstedt, P.T. (Stockholm): Effect of Dietary Protein and Amino Acid Mixture on Protein Synthesis in vitro in Rat Liver 325

Makris, A. and Gershoff, S.N. (Boston, Mass.): Insulin Sensitivity in Vitamin B $\beta-$

Deficient Rats. Effects of Acute and Chronic Growth Hormone Treatment 337

Gopalan, C; Krishnamurthi, D.; Shenolikar, I. S., and Krishnamachari,

K. A.V.R. (Hyderabad): Myocardial Changes in Monkeys Fed Mustard Oil .. 352 Lenk, W. (Munich): Nutritional and Metabolic Aspects of Heredopathia atactica polyneuritiformis (Refsum's Syndrome) 366

Mahoney, A.W. and Hendricks, D.G. (Logan, Ut.): Role of Gastric Acid in the

Utilization of Dietary Calcium by the Rat 375

Book reviews - Buchbesprechungen - Livres nouveaux 383

Author Index 384 
S. Karger · Basel · München · Paris · London · New York · Sidney Amold-Böcklin-Strasse 25, CH-4011 Basel (Schweiz)

All rights, including that of translation into other languages, reserved.

Photomechanic reproduction (photocopy, microcopy) of this book or parts thereof without special premission of the publishers is prohibited.

(C) Copyright 1974 by S. Karger AG, Verlag für Medizin und Naturwissenschaften, Basel Printed in Switzerland by Buchdruckerei Lüdin AG, Liestal 